\title{
ON AFTER-CARE OF PARALYSED PATIENTS IN THEIR HOME
}

\author{
By E. Meine, M.D. \\ From the Spinal Centre of the Surgical Department of the \\ Berufsgenossenschaftlichen Sonderstation Koblenz, Germany
}

IT is a well-established fact that paralysed patients cannot get the optimal treatment in general hospitals which are not equipped with adequate facilities (Guttmann, 1956; Leimbach, 1963). Only treatment in a special department gives these patients the possibility, in spite of their severe permanent disability, not only to have a higher chance for longer life expectancy, but also for a professional life according to their condition.

Germany has followed in the footsteps of Sir Ludwig Guttmann from Stoke Mandeville (England), and has done a lot in the last ten years in this direction (Leimbach, I957-63; Heipertz, I957). In particular, the Workers Insurance Unions (Berufsgenossenschaft) have opened in their Accident Hospitals well equipped departments for paralysed patients only, in which all the facilities are available in order to obtain the best clinical results, and at the same time everything is being done to rehabilitate and re-integrate these patients into society.

The people who are responsible for the treatment of these patients from the day of their accident till they leave the hospital fully rehabilitated are the doctor and nurse, the physiotherapist and physical trainer, the occupational therapist and, last but not least, the Welfare Officer of the Workers Insurance Union.

The paralysed patients are not only considered to be a group which require special treatment, but they also demand special care in other directions. Usually a normal patient who leaves the hospital does not need, with some exceptions, special after-care. Paralysed patients on the other hand need after-care during their whole life at regular intervals, which includes instructions in special exercises regardless of whether they do their training alone at home or in a group.

The Welfare Officer of the Workers Insurance Union is at their disposal and a paralysed patient can always ask for his help and guidance. However, there is a need to see patients in their own environment once they are discharged from hospital. After discussing this problem in detail with the Workers Insurance Union from Rheinland-Westfalen we have organised since I 7 January I 967 visits to paralysed patients living at home in an area of about 90 miles (I $50 \mathrm{~km}$.) in which a doctor, a physical trainer and also the Welfare Officer of the Workers Insurance Union take part.

We have compiled the results of these visits after taking the following aspects of the patient's situation into consideration:

I. Medical condition.

2. Home conditions.

3. Family conditions.

4. Professions or other occupations.

5. Financial situation.

6. Physical training (sport).

The medical conditions of the patients are summarised in Table I.

The results of our observation could be summed up as follows: The general health condition of most of the patients was satisfactory. 
Seventy-one per cent. live in their own home or with their parents, 63 per cent. have bathroom and bedroom on the same floor, 12 per cent. had no bathroom, I6 per cent. had special bed for paraplegics; 75 per cent. were married, 25 per cent. unmarried, 53 per cent. had children; 57 per cent. were completely dependent, 28 per cent. partially and I 5 per cent. independent.

Twenty-five per cent. of the patients visited showed bruises and pressure sores and we arranged for these patients to have treatment by their family doctor; I I per cent. needed hospital treatment.

\section{TABLE I}

Summary of the first 86 paralysed patients visited

i. Medical Condition

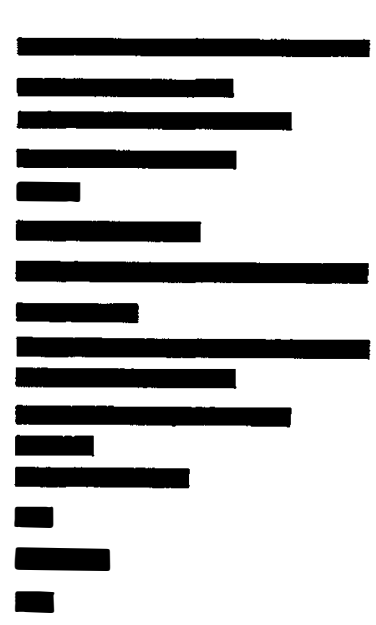

$\%$

Paraplegia between I2th thoracic and 2nd lumbar vertebrae Complete

56 Incomplete with dysfunction of bladder and bowels

44 Having supporting apparatus

13 Cannot use these

38 Orthopaedic shoes with peroneus appliance

Wheelchair-bound

Pressure sores or bruises

Chronic cysto-pyelitis with medical treatment

Hypertension as a symptom of beginning renal deficiency

Wearing a urinal

Using a catheter

Partial bladder control

6 Urinary fistula

19 Have to remain in bed for bowel evacuation

7 Abuse of drugs (alcohol or nicotine)

Six per cent. of the patients had urinary fistulae and were registered for operation. It was interesting to note that the family doctor's treatment was taken only in cases of chronic urinary infection.

Thirteen per cent. of the patients were not using the prescribed supporting apparatus, and also did not perform their daily exercises. Advice was given that by so doing their health would surely improve.

Fifty-six per cent. of the visited patients possessed a car, 43 per cent. had remunerative jobs, 7 per cent. home occupations. This comparatively low percentage of employment amongst the patients is not because they do not wish to work, but, in particular patients living in villages, because they find it very difficult to secure appropriate employment. In such cases the Welfare Officer of the Workers Insurance Union tries his best to help where he can. The average monthly income of a complete paraplegic is II3I DM ( $£$ II5, IOs.). This includes accident insurance pension, invalid pension, nursing allowance and additional allowance for clothing. We were able to interest 44 per cent. of the paralysed patients for our sports day which we organise once a month. Forty-two per cent. do not participate regularly. During the last National Sports Meeting in Murnau a selected group was successful in winning 27 medals.

We would also like to emphasise that during our visits we found patients who were living in home conditions which did not fulfil the requirements needed 
for a paralysed patient. We gave such cases exact advice and also made suggestions to the Workers Insurance Union. We are happy to state that all our suggestions have been carried out by that organisation.

We are of the opinion that after-care visits to paralysed patients in their homes is one of the most important and valuable ways of keeping contact with them and represents a step forward in their social re-integration. The contact between the paralysed patients and the Spinal Centre is very important and we all should make efforts in this direction.

\section{SUMMARY}

Since January 1967 the special department of Workers Insurance Union at Koblenz (West-Germany) has organised, with the help of a specialised doctor, physical trainer and a Welfare Officer, visits to paralysed patients in their home environment. From these visits a statistical study of 86 spinal paraplegic patients has been made.

The criteria for this study were medical condition, family, housing and financial conditions, professional and physical training. As a result of these visits it was possible to direct the patients to their family doctor when treatment was needed. Moreover, suggestions and requests regarding supporting and orthopaedic apparatus were made to the Workers Insurance Union.

A large number of patients could be interested in taking up physical training (sport) organised for paralysed patients. During the last National Sports Meeting for paralysed people a selected group was successful.

These visits make it possible to maintain close contact between the discharged paralysed patients and the Spinal Centre where they had been originally treated. Therefore, these visits should be considered important in the after-care of paraplegics.

\section{ZUSAMMENFASSUNG}

Seit Januar 1967 hat eine spezielle Abteilung der Berufsgenossenschaften gemeinsam mit einem Spezialarzt, Trainer und Fürsorger Besuche bei Querschnittsgelähmten in ihren Wohnungen organisiert. Aus diesen Besuchen wurden Statistiken an 86 Patienten erhoben.

Es wurden medizinische, familiäre, Wohnungs, finanzielle, berufliche und Training Verhältnisse untersucht. Aus diesen Besuchen ergaben sich ärztliche Ratschläge sowie Vorschläge für die Berufsgenossenschaften.

Ein grosse Zahl der Patienten zeigte Interesse für Sportstraining. Während des letzten nationalen Sportfestes nahm eine Gruppe mit Erfolg teil. Diese Besuche machen es möglich, engen Kontakt mit den Patienten aufrecht zu erhalten.

\section{RÉSUMÉ}

Depuis janvier 1967, les collaborateurs de l'assurance du travail, à Coblence, ont organisé, avec l'aide de médecins spécialités, d'un gymnaste, et d'un conseiller social, des visites auprès de malades paralysés dans leur foyer.

Une étude portant sur 86 paraplégiques a été faite. Les critères ont été:

- les conditions médicales, familiales, financières et de logement

- leur réadaptation professionnelle et physique.

Ces malades ont pu être, quand nécessaire, envoyé chez leur médecin traitant.

Des suggestions en ce qui concerne l'appareillage orthopédique, ont été émises. Beaucoup de malades ont été intéressés dans la participation aux sports. Un groupe sélectionné pour les jeux nationaux des paralysés a remporté un vif succès.

Ces visites permettent un contact étroit entre le malade revenu chez lui et le Centre où il a été traité, et de ce fait, doivent être considérées comme un facteur important dans les soins après leur sortie. 


\title{
REFERENCES
}

Guttmann, L. (1956). Dtsch. Z. Nervenheilk. 175, 173.

GutTManN, L. (1958). Int. Congr. of Rehabilitation, etc., Liepzig, I6I-165.

HeIPERTZ (1957). Arch. orth. Unfall-Chir. 48, 679-Tagung d. Deutsch. Ges. für Unfallheilkunde, Heidelberg 1956.

LeimbaCH, G. (I963). Hefte z. Unfallheilk., Heft 78, Verhandlungen der Dtsch. Gesellsch. für Unfallheilk., Versicherungs-, Versorgungs- und Verkehrsmedizin, XXVII. Tag. in Berlin 1963.

Leimbach, G. (1960). Diskussionsbeitrag zur Querschnittsgelähmtenfrage, Hefte z. Unfallheilkunde 66 (verh. Dtsch. Ges. für Unfallheilk. Lindau 1960).

Leimbach, G. (I96I). Die olymp. Spiele für Paraplegiker in Stoke Mandeville, Die Berufsgenossenschaft.

LeimbaCH, G. (1957). Berufsgenossenschaftliche Sonderstation im Rahmen des Unfallheiverfahrens, Monatskurse ärztl. Fortbild.

\section{SPINA BIFIDA AND THE PARAPLEGIC SERVICE}

\author{
By T. M. GreGG, M.D., F.R.C.P.I. \\ National Medical Rehalilitation Centre, Ireland
}

THE estimated incidence of meningocele and meningomyelocele in Southern Ireland is over 3 cases per Iooo live births. One survey returned a figure of 4 per 1000. With a population of $2,750,000$ and a birth rate of 62,000 per annum, this gives a figure of between 180 and 250 such cases. Not all of these are at present referred to centres for immediate operation.

The incidence in Liverpool of meningomyelocele and/or hydrocephalus taken from the Congenital Abnormalities Registry between 1960 and 1964 was 3.I live born per 1000 births. In Birmingham the registry from 1955 to I959 showed 2.5 per 1000. Rates in different parts of Britain vary from $\mathrm{I} \cdot 3$ to 3 per 1000 (General Register Office).

Up to I2 years ago 94 per cent. of babies born with spina bifida cystica died of meningitis and 4 per cent. remained as wheelchair cases. Immediate operation within 24 hours of birth dramatically alters this outlook and prevents increase in paralysis. Ventriculo-cardiac drainage to control hydrocephalus has also completely altered the prognosis. Sharrard's results show 70 per cent. of these post-operative children surviving to school-going age. Of these, one-third have little or no paralysis, one-third with coincident myelodysplasia have moderate paralysis, but with corrective orthopaedic procedure can walk with minimal or no splintage. Onethird, however, have severe flaccid or upper motor neurone paraplegia of varying degree, many being wheelchair cases.

There is an increasing number of these children being operated on early in Ireland, and it is possible that this figure will increase to I80/200 per annum. If we have similar success to Sheffield, it means that we can expect up to 40 or possibly more paraplegic cases of different severity surviving per annum from this cause alone. If we were to include all those with some lower limb paralysis and some bladder disturbance the figure would be higher.

We get about 40 traumatic paraplegic cases per annum, the majority of them incomplete. We also admit about 20 other cases of non-traumatic paraplegia, not including cases of multiple sclerosis. 